Check for updates

Cite this: RSC Adv., 2018, 8, 21993

Received 17th April 2018

Accepted 5th June 2018

DOI: 10.1039/c8ra03271h

rsc.li/rsc-advances

\section{Raw walnut shell modified by non-thermal plasma in ultrafine water mist for adsorptive removal of $\mathrm{Cu}($ II) from aqueous solution}

\author{
Long $\mathrm{Wu}^{\mathrm{ab}}$ Zhongsheng Shang, ${ }^{\mathrm{a}}$ Shixian Chen, ${ }^{\mathrm{a}}$ Jiayong Tu, ${ }^{\mathrm{a}}$ Noriyuki Kobayashi ${ }^{\mathrm{C}}$ \\ and Zhanyong $\mathrm{Li}$ (iD *ab
}

\begin{abstract}
Non-thermal plasma in ultrafine water mist (UWM) is proposed to increase the content of $\mathrm{COOH}$ groups on the surface of raw walnut shell in order to improve its performance in the removal of $\mathrm{CU}(I)$ from wastewater. The modified walnut shell surface was characterized by various techniques (BET, SEM-EDX and XPS), and it was observed that more $\mathrm{COOH}$ groups were generated. Oxygen disassociated from water mist by plasma bonded with the walnut shell to form activated sites of $\mathrm{COOH}$ groups. After $\mathrm{Cu}(I)$ adsorption, the $\mathrm{COOH}$ group content in the walnut shell decreased because some groups were changed into $\mathrm{C}-\mathrm{O}$ groups by $\mathrm{Cu}(I I)$ chemisorption with $\mathrm{COOH}$ groups. The $\mathrm{Cu}(I)$ removal efficiency was $33.5 \%$ for raw walnut shell; however, the efficiency increased to $98 \%$ after plasma modification for 15 min under $3 \mathrm{~g} \mathrm{~min}^{-1}$ water mist. The maximum $\mathrm{Cu}(I)$ adsorption capacity of the UWM-plasma-modified WNS was $39.4 \mathrm{mg} \mathrm{g}^{-1}$ at $\mathrm{pH} 5.3$ and $25{ }^{\circ} \mathrm{C}$, around 8 times that of the raw WNS. This implies that UWM-plasma modification is a potential method for improving the $\mathrm{Cu}(I)$ adsorption performance of raw biomass.
\end{abstract}

\section{Introduction}

Copper ion $(\mathrm{Cu}(\mathrm{II}))$ is a wastewater contaminant that is mainly discharged from industrial procedures of metal cleaning, mining, metal-process picking, chemical manufacturing and plating. ${ }^{1} \mathrm{Cu}$ (II) is one of the most toxic heavy metals; it can accumulate in living organisms via the food chain as a nonbiodegradable pollutant, leading to serious damage to the human body. ${ }^{2}$ In order to remove $\mathrm{Cu}(\mathrm{II})$ from wastewater before inflowing into human water resources, many techniques, such as adsorption, chemical precipitation, ion exchange, biosorption, membrane separation and electrocoagulation, have been developed. . $^{3,4}$ Among these, adsorption is considered to be an effective and economic technology because various adsorbents can be produced from agricultural and forestry residues (usually biomass) with significance for "dealing with waste by waste". ${ }^{5-7}$

Biomass has advantages of low cost and sustainable availability. Through pyrolysis and physical or chemical treatment of biomass, products such as biochar, activated carbon and

${ }^{a}$ Tianjin International Joint Research and Development Center of Low-Carbon Green Process Equipment, College of Mechanical Engineering, Tianjin University of Science \& Technology, Tianjin 300222, China. E-mail: zyli@tust.edu.cn; Fax: +86022 60600702; Tel: +8602260600702

${ }^{b}$ Tianjin Key Laboratory of Integrated Design and On-line Monitoring for Light Industry \& Food Machinery and Equipment, Tianjin 300222, China

'Department of Chemical Engineering, Nagoya University, Furo-cho, Chikusa-ku, Nagoya, Aichi 464-8603, Japan synthesized adsorbents have been used for adsorption of $\mathrm{Cu}(\mathrm{II})$ and/or other heavy metal ions with favorable physical/chemical surface properties. ${ }^{8}$ Biochar is usually produced from incomplete pyrolysis of carbon-rich biomass at $300{ }^{\circ} \mathrm{C}$ to $900{ }^{\circ} \mathrm{C}$ for several hours. ${ }^{9}$ Biochar has good sorption ability for $\mathrm{Cu}(\mathrm{II})$ due to its abundance of oxygen-containing functional groups. ${ }^{1}$ Many researchers have modified biochar using chemical agents (such as $\mathrm{FeCl}_{3}$ and $\mathrm{ZnCl}_{2}$ ) to further improve its adsorption performance. ${ }^{10}$ Activated carbon with a highly developed porous texture for favorable adsorption performance was produced in high-temperature $\left(500{ }^{\circ} \mathrm{C}\right.$ to $\left.900{ }^{\circ} \mathrm{C}\right)$ atmosphere involving activating agents, such as $\mathrm{H}_{2} \mathrm{O}(\mathrm{g})$ and $\mathrm{CO}_{2}$ for physical activation and $\mathrm{ZnCl}_{2}, \mathrm{KOH}, \mathrm{K}_{2} \mathrm{CO}_{3}$ and $\mathrm{H}_{3} \mathrm{PO}_{4}$ for chemical activation. ${ }^{11-13}$ The synthesized adsorbent was produced with selected chemical agents to develop specific functional groups for target ion removal. This process is usually carried out at $40{ }^{\circ} \mathrm{C}$ to $60^{\circ} \mathrm{C}$ and consumes a large number of chemical agents. ${ }^{14}$ The abovementioned processes for preparing biomass-derived adsorbents necessitate high energy consumption and chemical disposal. It is desirable to construct a simple, low-energyconsuming and environmentally friendly process for adsorbent production.

To achieve this objective, non-thermal plasma in ultrafine water mist (UWM) was employed to modify raw biomass; then, the modified biomass was directly used as an adsorbent for $\mathrm{Cu}$ (II) removal. It is known that non-thermal plasma can generate energetic electrons and highly active radicals that increase the active functional groups on the surface of adsorbents. ${ }^{15,16}$ The plasma modification equipment is simple and 
consumes low energy; neither high temperature pyrolysis nor chemical agents are involved. Moreover, $\mathrm{H}_{2} \mathrm{O}$ plasma media is clean, inexpensive and readily available. It has been reported that water vapor plasma can generate oxygen-containing functional groups, ${ }^{17}$ which have positive effects on the $\mathrm{Cu}$ (II) adsorption process. ${ }^{18}$ In the literature, ${ }^{17,19,20}$ an additional heat source (i.e. $60{ }^{\circ} \mathrm{C}$ to $100{ }^{\circ} \mathrm{C}$ ) and/or vacuum conditions were required to change liquid water to vapor (gas-phase) in an experimental plasma system. However, this method requires a complex device system and is expensive. In this study, instead, a simple and effective method is proposed where ultrafine water mist is first introduced by atomization in ambient temperature for non-thermal plasma modification of raw biomass. The effects of modification time, UWM mass flow rate and different plasma atmospheres on $\mathrm{Cu}(\mathrm{II})$ removal efficiency were investigated. Brunauer-Emmett-Teller (BET), scanning electron microscopy, energy dispersive X-ray (SEM-EDX) and X-ray photoelectron spectroscopy (XPS) tests were also conducted to explore the UWM-plasma modification process and $\mathrm{Cu}(\mathrm{II})$ adsorption mechanisms on modified walnut shell.

\section{Materials and methods}

\subsection{Sample pretreatment}

The walnut shell (WNS) used in this study was collected from Tianjin, China. The raw walnut shell was ground and sieved to a particle size of 0.35 to $0.56 \mathrm{~mm}$ and then washed with distilled water to remove impurities. The moisture in the walnut shell particles was removed by drying for $12 \mathrm{~h}$ at $105^{\circ} \mathrm{C}$.

Fig. 1a shows the experimental setup of non-thermal UWMplasma modification. The non-thermal plasma was generated using a dielectric barrier discharge (DBD) reactor (DBD-100A, CTP-2000K, Suman Corporation, China). Two quartz circular plates $70 \mathrm{~mm}$ in diameter and $3 \mathrm{~mm}$ thick were used as barrier materials, and two stainless steel plates $50 \mathrm{~mm}$ in diameter were used for electrodes. The barrier-to-barrier gap was $8 \mathrm{~mm}$. $1.0 \mathrm{~g}$ of walnut shell particles were evenly spread in the DBD plasma reactor. An ultrasonic nebulizer was used to atomize the distilled water into an ultrafine mist 1 to $10 \mu \mathrm{m}$ in diameter at room temperature $\left(25{ }^{\circ} \mathrm{C}\right)$, as shown in Fig. $1 \mathrm{~b}$. Then, the ultrafine water mist and highly pure Ar (99.9\%, vol. base) were mixed and introduced into the plasma reactor at room temperature. The gas flow rate of $\mathrm{Ar}$ was maintained as

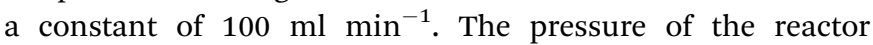
chamber was controlled at $95 \mathrm{kPa}$ via a vacuum pump (BUCHI, Switzerland). Each flow rate was adjusted using a mass flow meter. The UWM mass flow rate was varied from 0.5 to 3 $\mathrm{g} \mathrm{min}^{-1}$. The modified walnut shell was designated as WNS$\mathrm{W} x \mathrm{~T} y$ according to different processing conditions. W $x$ denotes $x \mathrm{~g} \min ^{-1}$ of UWM mass flow rate, and Ty denotes $y$ minute of plasma modification time. For example, WNS-W3T15 indicates that the WNS was modified by plasma in $3 \mathrm{~g} \mathrm{~min}^{-1} \mathrm{UWM}$ for 15 min. Additionally, samples of WNS-W3 (the WNS was placed in $3 \mathrm{~g} \mathrm{~min}{ }^{-1} \mathrm{UWM}$ atmosphere for $15 \mathrm{~min}$ without non-thermal plasma modification) and WNS-T15 (the WNS was modified

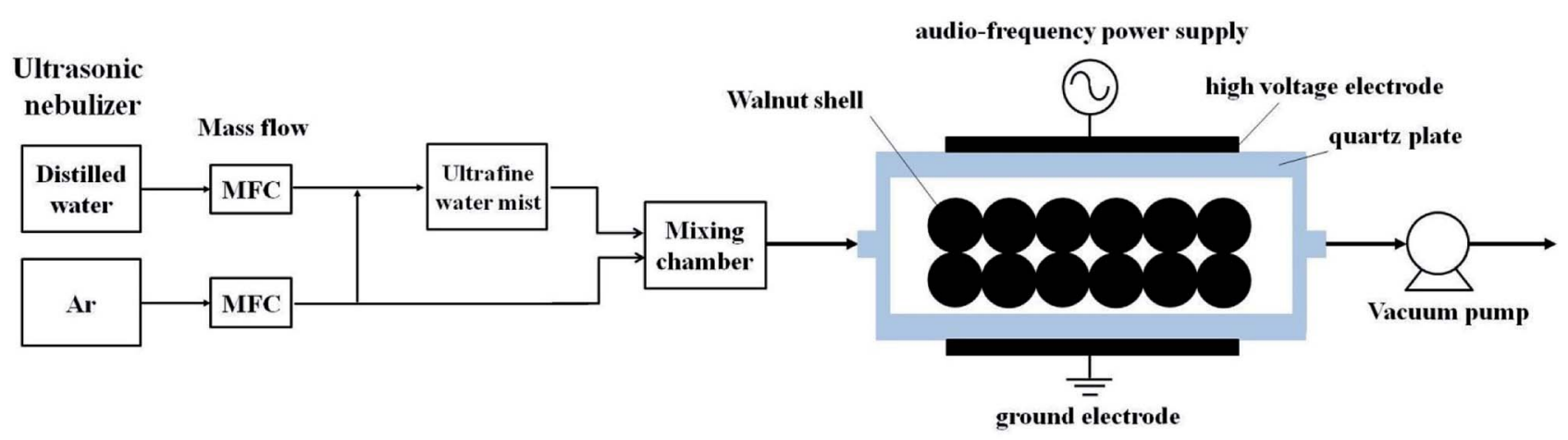

(a)

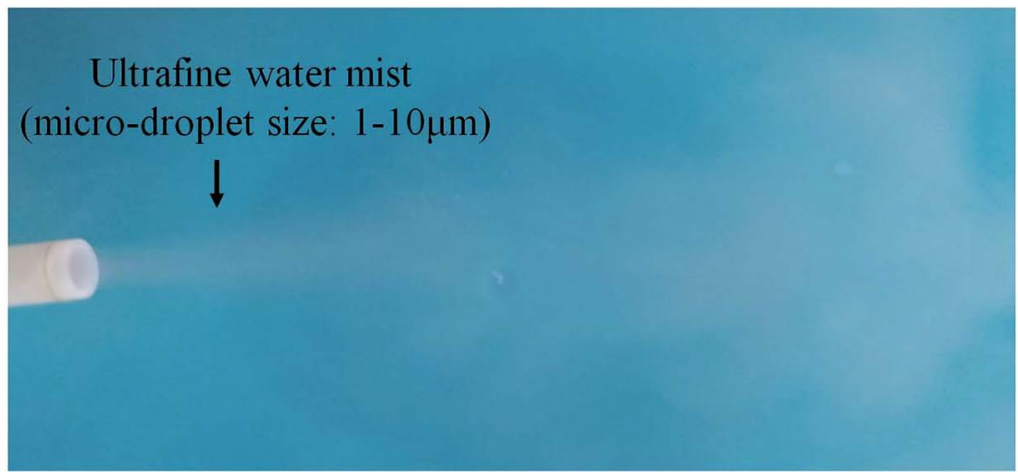

(b)

Fig. 1 (a) Schematic of the treatment system of non-thermal plasma in ultrafine water mist and (b) image of the ultrafine water mist. 
with non-thermal plasma under Ar atmosphere without UWM) were compared to study the effects of UWM-plasma modification on the $\mathrm{Cu}$ (II) adsorption performance of walnut shell. The non-thermal plasma was produced in the DBD reactor via an alternating current with a $10 \mathrm{kHz}$ audio frequency and $5 \mathrm{kV}$ peak voltage. A digital oscilloscope was used to measure the input power via Lissajous diagrams. The discharge power for nonthermal plasma was $75 \mathrm{~W}$.

\subsection{Chemicals}

The stock solutions of $\mathrm{Cu}(\mathrm{II})$ were prepared by dissolving $\mathrm{CuSO}_{4} \cdot 5 \mathrm{H}_{2} \mathrm{O}$ in deionized water to a concentration of $1.0 \mathrm{~g} \mathrm{~L}^{-1}$ and then diluting this solution to the appropriate concentration for each test. All chemicals used in this study were of analytical grade.

\section{3. $\mathrm{Cu}(\mathrm{II})$ adsorption}

Batch adsorption experiments were conducted by mixing $0.5 \mathrm{~g}$ prepared walnut shell samples with $50 \mathrm{ml}$ prepared $\mathrm{Cu}$ (II) solution at the natural solution $\mathrm{pH}$ (5.3). The $\mathrm{Cu}(\mathrm{II})$ adsorption experiments were performed in a thermostated rotary shaker (ZWY-103B, ZHICHENG Corporation, China) for a period of $2 \mathrm{~h}$ at $300 \mathrm{rpm}$ using a $100 \mathrm{ml}$ screw-cap conical flask with $50 \mathrm{ml}$ prepared $\mathrm{Cu}$ (II) solution at room temperature $\left(25 \pm 0.5{ }^{\circ} \mathrm{C}\right)$. Before measuring the $\mathrm{Cu}$ (II) concentration in the solution for each case, the adsorbent was separated from the sample by filtering after adsorption at different time intervals. Then, the remaining concentration of $\mathrm{Cu}(\mathrm{II})$ in the filtrate was analyzed by a Cu(II) meter (S220 SevenCompact ion meter, Mettler-Toledo, Switzerland) with an accuracy of $\pm 0.5 \%$. In order to ensure good repeatability of the experimental data, each measurement was repeated at least three times. The error bars of the data were estimated based on the standard deviation of the measurements. The $\mathrm{Cu}$ (II) removal efficiency $\left(\eta_{\mathrm{t}}, \%\right)$ was determined according to the following equation:

$$
\eta_{t}=\frac{C_{0}-C_{t}}{C_{0}} \times 100 \%
$$

where $C_{0}\left(\mathrm{mg} \mathrm{L}^{-1}\right)$ is the initial $\mathrm{Cu}(\mathrm{II})$ concentration and $C_{t}(\mathrm{mg}$ $\mathrm{L}^{-1}$ ) is the $\mathrm{Cu}(\mathrm{II})$ concentration at a contact time of $t$.

\subsection{Regeneration tests}

Adsorption-desorption regeneration cycle tests for $\mathrm{Cu}$ (II) removal were conducted to investigate the possibility of repeated use of the UWM-plasma modified WNS. The adsorption test was conducted at $\mathrm{pH} 5.3$ with an initial $\mathrm{Cu}$ (II) concentration of $100 \mathrm{mg} \mathrm{L}^{-1}$, adsorbent dosage of $0.5 \mathrm{~g} / 50 \mathrm{ml}$ and agitation speed of $300 \mathrm{rpm}$. When the desorption test was conducted, the $\mathrm{Cu}(\mathrm{II})$-loaded adsorbent was stirred with $0.1 \mathrm{~mol} \mathrm{~L}^{-1} \mathrm{HCl}$ solution $(\mathrm{pH} 2)$ and was allowed $120 \mathrm{~min}$ of contact time at $25{ }^{\circ} \mathrm{C}$ (room temperature). The adsorption and desorption procedures were repeated for three cycles using the same activated carbon in different solutions.

\subsection{Data analysis}

The adsorption isotherms of $\mathrm{Cu}$ (II) on raw WNS and UWMplasma modified WNS were fitted with the Langmuir model in this study.

$$
\frac{C_{\mathrm{e}}}{q_{\mathrm{e}}}=\frac{1}{Q_{\max } b}+\frac{C_{\mathrm{e}}}{Q_{\max }}
$$

where $Q_{\max }\left(\mathrm{mg} \mathrm{g}^{-1}\right)$ is the maximum capacity; $b\left(\mathrm{~L} \mathrm{mg}^{-1}\right)$ is the Langmuir adsorption constant; $C_{\mathrm{e}}\left(\mathrm{mg} \mathrm{L}^{-1}\right)$ is the equilibrium concentration of $\mathrm{Cu}(\mathrm{II})$; and $q_{\mathrm{e}}\left(\mathrm{mg} \mathrm{g}^{-1}\right)$ is the amount of $\mathrm{Cu}(\mathrm{II})$ adsorbed per unit mass of adsorbent at equilibrium.

The Pseudo-first-order model, Pseudo-second-order model and Weber-Morris model were implemented to analyze the adsorption kinetics of $\mathrm{Cu}(\mathrm{II})$ on raw WNS and UWM-plasma modified WNS:

$$
\begin{gathered}
\text { Pseudo-first-order model: } \ln \left(q_{\mathrm{e}}-q_{t}\right)=\ln q_{\mathrm{e}}-k_{1} t \\
\text { Pseudo-second-order model : } \frac{t}{q_{t}}=\frac{1}{k_{2} q_{\mathrm{e}}^{2}}+\frac{1}{q_{\mathrm{e}}} t \\
\text { Weber - Morris model : } q_{t}=k_{\mathrm{int}} t^{\frac{1}{2}}+C
\end{gathered}
$$

where $k_{1}\left(\min ^{-1}\right)$ is the rate constant of the Pseudo-first-order equation; $k_{2}\left(\mathrm{~g}\left(\mathrm{mg}^{-1} \mathrm{~min}^{-1}\right)\right)$ is the rate constant of the Pseudo-second-order equation; $k_{\text {int }}\left(\mathrm{mg}\left(\mathrm{g}^{-1} \mathrm{~min}^{1 / 2}\right)\right)$ is the intraparticle diffusion rate constant; and $C\left(\mathrm{mg} \mathrm{g}^{-1}\right)$ is a constant related to the boundary layer effect of adsorption.

\subsection{Sample characterization}

The textural properties of the raw walnut shell and plasma modified walnut shell particles were determined by measuring $\mathrm{N}_{2}$ adsorption-desorption isotherms at $77 \mathrm{~K}$ (Belsorp-max, MicrotracBEL Corp., Japan). The morphological features of the samples were characterized by scanning electron microscopy (SEM, Nanosem 430, FEI, USA), and their elemental compositions $(\mathrm{C} / \mathrm{N} / \mathrm{O} / \mathrm{P} / \mathrm{Cu})$ were analysed by energy dispersive $\mathrm{X}$-ray (EDX). The surface bindings of the samples were characterized by X-ray photoelectron spectroscopy (XPS) with surface excitation at $1253 \mathrm{eV}$ by an Mg X-ray source (PHI 5300 ESCA system, PerkinElmer, USA). The XPS spectra were calibrated by setting the binding energy of $\mathrm{C}_{1 \mathrm{~s}}$ at $285 \mathrm{eV}$.

\section{Results and discussion}

Fig. 2a shows the $\mathrm{Cu}(\mathrm{II})$ removal efficiencies of raw WNS, WNSW8, WNS-T15 and WNS-W8T15. For each sample, the $\mathrm{Cu}$ (II) removal efficiency increased with adsorption contact time and reached an equilibrium value in about $90 \mathrm{~min}$; it then maintained a constant value with further increase in contact time. Thus, the adsorption duration was fixed at $120 \mathrm{~min}$ to assure that equilibrium was reached. As shown in Fig. 2a, the $\mathrm{Cu}$ (II) removal ability of raw WNS was poor; its removal efficiency was only $33.5 \%$. The $\mathrm{Cu}(\mathrm{II})$ removal performance of WNS-W3 and WNS-T15 was similar to that of raw WNS. This indicates that the process of placing the WNS in UWM atmosphere without nonthermal plasma modification had no effect on the WNS. Also, 


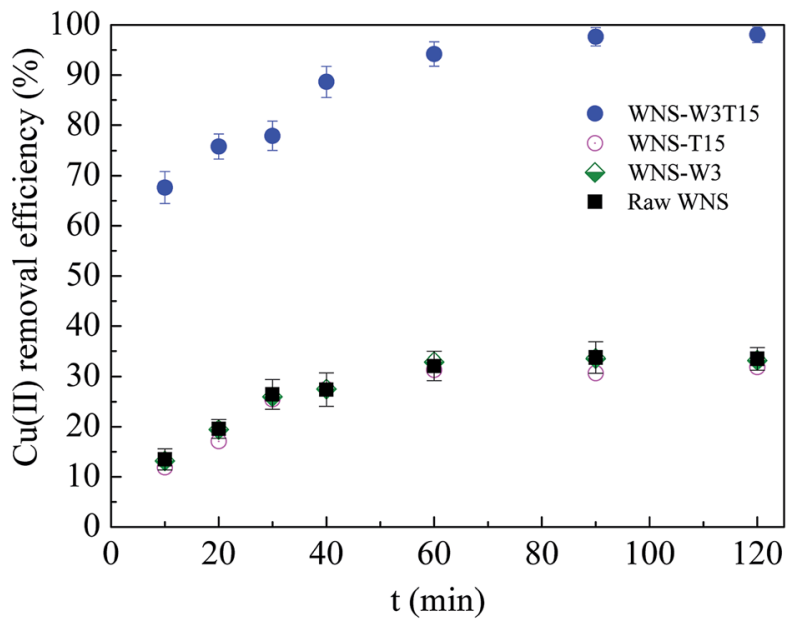

(a)

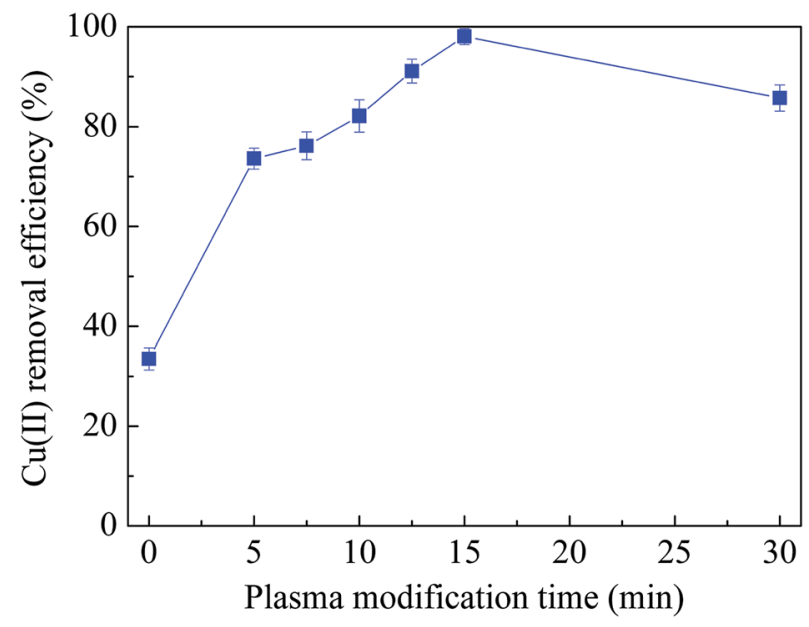

(b)

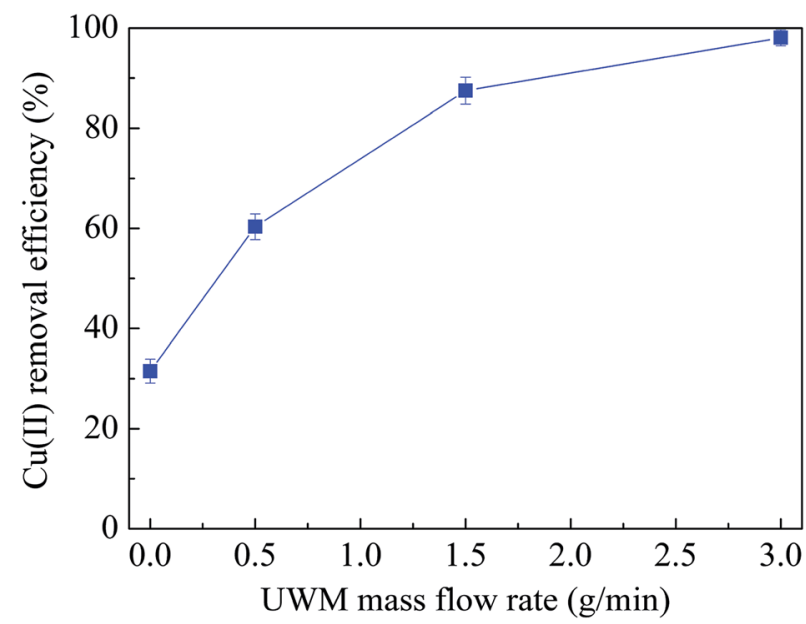

(c)

Fig. 2 (a) $\mathrm{Cu}($ (I) removal efficiency curves of raw WNS, WNS-W3 (placed in $3 \mathrm{~g} \mathrm{~min}^{-1}$ UWM for $15 \mathrm{~min}$ without plasma modification), WNS-T15 (modified by plasma in Ar without UWM for $15 \mathrm{~min}$ ), and WNS-W3T15 (modified by plasma with $3 \mathrm{~g} \mathrm{~min}^{-1}$ UWM for $15 \mathrm{~min}$ ); (b) effects of plasma modification time on $\mathrm{Cu}(\mathrm{II})$ removal efficiency; (c) effects of UWM mass flow rate on Cu(II) removal efficiency. (Conditions: $T=25^{\circ} \mathrm{C}, \mathrm{pH} 5.3$, initial $\mathrm{Cu}(॥)$ concentration: $100 \mathrm{mg} \mathrm{L}^{-1}$ ).

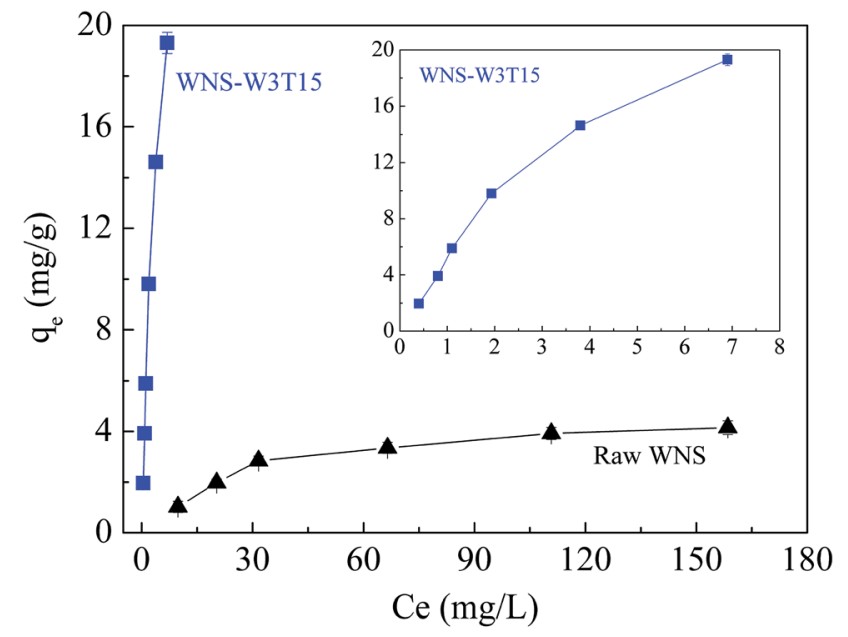

(a)

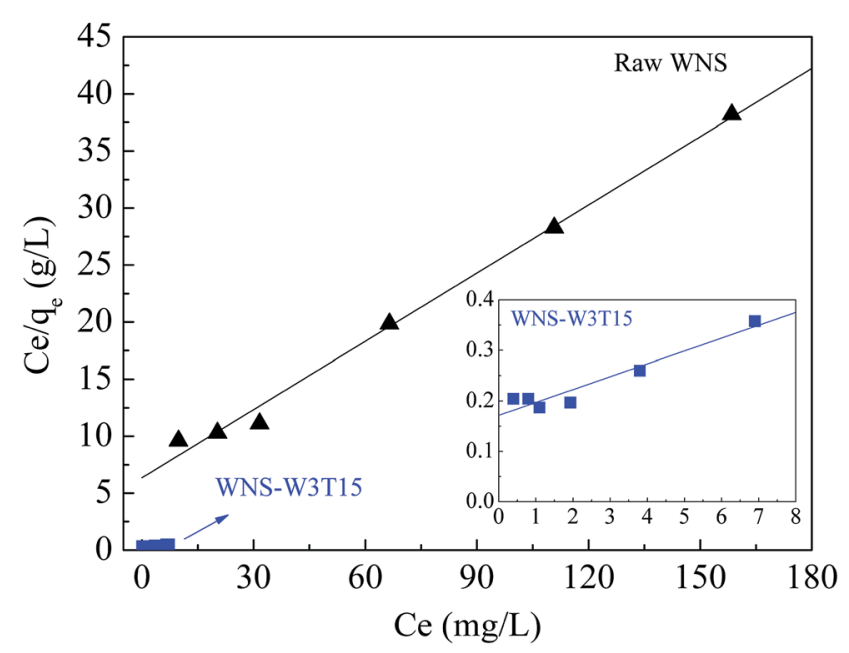

(b)

Fig. 3 (a) Adsorption isotherms of Cu(॥) on raw WNS andWNS-W3T15; (b) the Langmuir isotherm model for $\mathrm{Cu}(\|)$ adsorption on raw WNS and WNS-W3T15. (Conditions: $T=25^{\circ} \mathrm{C}, \mathrm{pH}$ 5.3).

the process of modification with non-thermal plasma without UWM did not enhance the $\mathrm{Cu}(\mathrm{II})$ removal performance of WNS. In contrast, UWM-plasma modification showed a significant positive effect on the $\mathrm{Cu}$ (II) removal efficiency of WNS. The removal efficiency of WNS-W3T15 reached 98\%, which is promising for the removal of $\mathrm{Cu}$ (II) from wastewater. This indicates that non-thermal UWM-plasma modification greatly increased the $\mathrm{Cu}(\mathrm{II})$ removal efficiency of WNS. Meanwhile,

Table 1 Isotherm parameters for $\mathrm{Cu}($ (I) adsorption onto raw WNS and WNS-W3T15

\begin{tabular}{llll}
\hline & \multicolumn{2}{l}{ Langmuir model } & \\
\cline { 2 - 4 } Sample & $Q_{\max }\left(\mathrm{mg} \mathrm{g}^{-1}\right)$ & $b\left(\mathrm{~L} \mathrm{mg}^{-1}\right)$ & $R^{2}$ \\
\hline Raw WNS & 5.02 & 0.031 & 0.994 \\
WNS-W3T15 & 39.4 & 0.148 & 0.927
\end{tabular}


Table 2 Adsorption capacities of $\mathrm{Cu}($ (I) by various adsorbents

\begin{tabular}{|c|c|c|c|c|}
\hline Activated carbon source & $\mathrm{pH}$ & Temperature $\left({ }^{\circ} \mathrm{C}\right)$ & $q_{\mathrm{e}}\left(\mathrm{mg} \mathrm{g}^{-1}\right)$ & Reference \\
\hline Rice husk-based activated carbon & 5 & 40 & 15.8 & 12 \\
\hline Poplar sawdust-based activated carbon & 5 & 20 & 13.5 & 22 \\
\hline Walnut shell-based activated carbon & 5 & 40 & 28.4 & 24 \\
\hline Phaseolus aureus hull-based activated carbon & 7 & 30 & 19.5 & 25 \\
\hline Apricot stone-based activated carbon & 6.5 & 25 & 22.8 & 26 \\
\hline Raw walnut shell & 5.3 & 25 & 5.02 & This study \\
\hline UWM-plasma modified walnut shell & 5.3 & 25 & 39.4 & This study \\
\hline
\end{tabular}

UWM and non-thermal plasma were both requisite factors for WNS modification.

Fig. $2 \mathrm{~b}$ shows the effects of plasma modification time ( 0 to 30 min) with $3 \mathrm{~g} \mathrm{~min}^{-1} \mathrm{UWM}$ on the $\mathrm{Cu}(\mathrm{II})$ removal efficiency of WNS. The modification time of 0 min represents raw WNS without plasma modification. It can be seen that the $\mathrm{Cu}(\mathrm{II})$ removal efficiencies on the WNS modified with UWM-plasma were significantly higher than those on the raw WNS (modified for $0 \mathrm{~min}$ ). The WNS modified for only $5 \mathrm{~min}$ by nonthermal plasma with $3 \mathrm{~g} \min ^{-1}$ UWM triggered a sharp increase in the removal efficiency from $33.5 \%$ to $74 \%$. With increasing modification time from 5 to $15 \mathrm{~min}$, the removal efficiency gradually increased from $74 \%$ to $98 \%$. However, a further increase to 30 min modification time had a negative effect on the removal efficiency, where the efficiency decreased to $85.7 \%$. This indicates that the use of UWM-plasma to modify WNS can effectively improve its removal efficiency for $\mathrm{Cu}$ (II). Moreover, the optimum plasma modification time should be considered because excess modification has a negative effect on $\mathrm{Cu}(\mathrm{II})$ removal. The use of UWM-plasma was proposed to modify the WNS by producing more O-containing groups on the WNS surface, which are important for $\mathrm{Cu}$ (II) adsorption. Thus, the UWM mass flow rate (i.e. the $\mathrm{H}_{2} \mathrm{O}$ content in the plasma system), which determines the amount of O-containing groups during the plasma modification process, ${ }^{17,21}$ affects the $\mathrm{Cu}(\mathrm{II})$ removal performance of modified WNS. The effects of the UWM mass flow rate on $\mathrm{Cu}$ (II) removal efficiency with $15 \mathrm{~min}$ plasma modification are shown in Fig. 2c. The results show that the UWM mass flow rate had a positive effect on the removal efficiency, where the $\mathrm{Cu}(\mathrm{II})$ removal efficiency generally increased with the UWM mass flow rate: WNS-W3T15 $(98 \%)>$ WNSW1.5T15 $(87.5 \%)>$ WNS-W0.5T15 $(60.3 \%)>$ WNS-T15 $(31.5 \%)$. It can be inferred that the content of O-containing groups increased with increasing UWM mass flow rate during the plasma modification process, resulting in improvement of the $\mathrm{Cu}(\mathrm{II})$ adsorption performance.

Fig. $3 \mathrm{a}$ and $\mathrm{b}$ show the adsorption isotherms of $\mathrm{Cu}$ (II) on raw WNS and WNS-W3T15 and the regression plots of the Langmuir isotherm model, respectively. The kinetics parameters obtained from the Langmuir model are listed in Table 1 . It can be observed that the adsorption data of $\mathrm{Cu}(\mathrm{II})$ by raw WNS and WNS-W3T15 were well fitted by the Langmuir model $\left(R^{2}\right.$ values in the range of 0.927 to 0.994$)$, indicating that the $\mathrm{Cu}(\mathrm{II})$ adsorption by raw WNS and UWM-plasma modified WNS involved monolayer coverage. Importantly, the maximum $\mathrm{Cu}(\mathrm{II})$ adsorption capacity of WNS-W3T15 is $39.4 \mathrm{mg} \mathrm{g}^{-1}$, nearly 8 times that of the raw WNS $\left(5.02 \mathrm{mg} \mathrm{g}^{-1}\right)$. Table 2 lists some other adsorbents for $\mathrm{Cu}(\mathrm{II})$ adsorption as reported in the literature for comparison. It can be seen that the UWM-plasma modified WNS in this study had a much higher adsorption

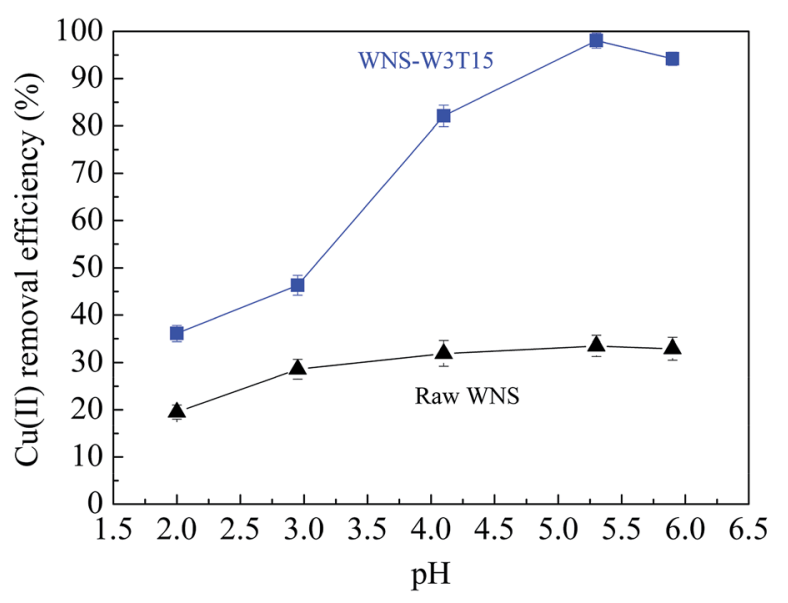

(a)

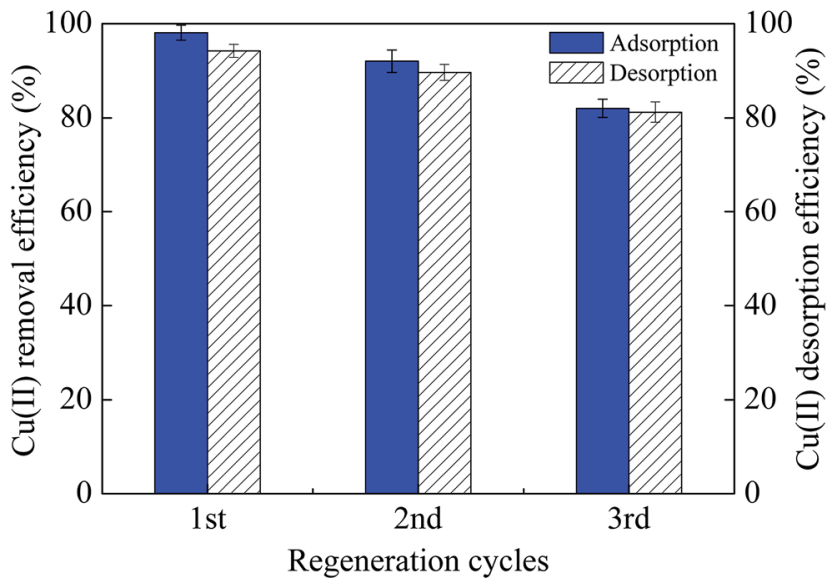

(b)

Fig. 4 (a) Effects of $\mathrm{pH}$ on the $\mathrm{Cu}(॥)$ removal efficiency of raw WNS and WNS-W3T15 (conditions: $T=25{ }^{\circ} \mathrm{C}$, initial $\mathrm{Cu}(I)$ concentration: $100 \mathrm{mg} \mathrm{L}^{-1}$ ); (b) the $\mathrm{Cu}(\mathrm{II})$ adsorption-desorption regeneration properties of WNS-W3T15. 


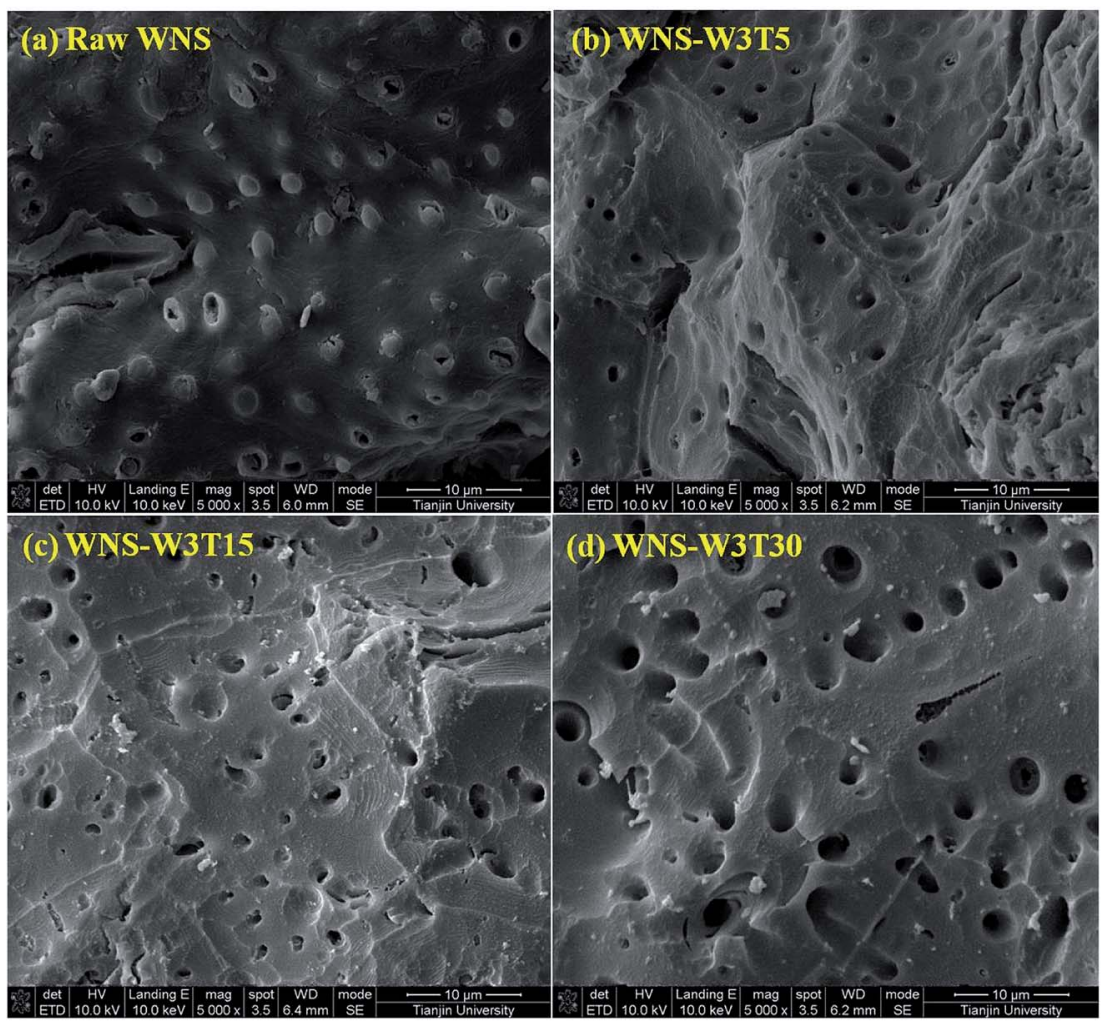

Fig. 5 SEM images of (a) raw WNS; (b) WNS-W3T5; (c) WNS-W3T15; (d) WNS-W3T30 (magnification: 5000×).

capacity than commercial activated carbon and other activated carbons derived from biomass. ${ }^{12,22-27}$ Fig. 4 a shows the $\mathrm{Cu}$ (II) removal efficiencies for raw WNS and WNS-W3T15 under different $\mathrm{pH}$ conditions. Generally, the $\mathrm{Cu}$ (II) removal efficiency increased with increasing $\mathrm{pH}$ for both raw WNS and WNSW3T15. Moreover, the Cu(II) removal efficiency of WNS-W3T15 was much higher than that of raw WNS for each $\mathrm{pH}$ value. Fig. $4 \mathrm{~b}$ shows the $\mathrm{Cu}(\mathrm{II})$ adsorption-desorption regeneration results of WNS-W3T15. Although a decrease of the $\mathrm{Cu}$ (II) removal efficiency was observed, WNS-W3T15 still exhibited good adsorption performance after three cycles of regeneration, where the $\mathrm{Cu}$ (II) removal efficiency was approximately $82 \%$. This demonstrates that UWM-plasma-modified WNS possesses excellent reusability for $\mathrm{Cu}$ (II) removal. In terms of practical use considerations, walnut shell can be readily obtained in large quantities, and the corresponding cost is much lower than that of activated carbon. Importantly, the UWM-plasma modified method used in this study is simple, inexpensive and nonchemical. Thus, UWM-plasma modification on walnut shell is a promising and feasible method for $\mathrm{Cu}(\mathrm{II})$ removal in environmental applications.

The surface physical (porous structure) and chemistry (functional groups) properties of a carbon adsorbent determine its adsorption process of ionic species from solution. Porous structure is an important factor for physical adsorption, while surface functional groups play key roles in specific adsorption and surface reactions. ${ }^{28}$ The UWM-plasma modification increased the $\mathrm{Cu}(\mathrm{II})$ adsorption capacity of WNS, which implies that the porous structure and surface functional groups were changed during the plasma modification process. The surface morphologies and element analyses of raw WNS and UWMplasma modified WNS from SEM-EDX analysis are shown in Fig. 5 and Table 3, respectively. Fig. 5 shows that the surface of raw WNS was rough and uneven and its structure was less porous. After the UWM-plasma modification, the surface of WNS presented an obviously porous structure with many craters and was covered with small particles. Moreover, the pore size increased after increasing the modification time. This can be ascribed to the plasma etching effect. ${ }^{29,30}$ Highly energetic electrons and active free radicals bombarded the external surface of WNS and produced the pore structure. Prolonged plasma modification time strengthened the etching effect and broadened the pore size. The specific surface areas of raw WNS and UWM-plasma modified WNS are shown in Table 3. After plasma modification, the specific surface area of WNS increased. This phenomenon is consistent with the results of

Table 3 Properties of raw and UWM-plasma modified walnut shell

\begin{tabular}{lllllll}
\hline & \multicolumn{7}{l}{ Element analysis (wt\%) } & \\
\cline { 2 - 6 } Sample & $\mathrm{C}$ & $\mathrm{N}$ & $\mathrm{O}$ & $\mathrm{P}$ & $\mathrm{Cu}$ & $S_{\text {BET }}\left(\mathrm{m}^{2} \mathrm{~g}^{-1}\right)$ \\
\hline Raw WNS & 50.4 & 4.06 & 44.33 & 1.21 & 0.0 & 0.56 \\
WNS-W3T5 & 45.72 & 5.7 & 47.52 & 1.06 & 0.0 & 0.71 \\
WNS-W0.5T15 & 47.48 & 5.84 & 45.41 & 1.28 & 0.0 & 1.11 \\
WNS-W1.5T15 & 48.06 & 4.36 & 46.72 & 0.86 & 0.0 & 0.95 \\
WNS-W3T15 & 44.09 & 5.11 & 50.01 & 0.8 & 0.0 & 0.88 \\
Used WNS-W3T15 & 42.8 & 6.31 & 46.8 & 1.34 & 2.75 & - \\
WNS-W3T30 & 45.21 & 7.58 & 45.14 & 2.07 & 0.0 & 1.06
\end{tabular}


the SEM analysis. However, the specific surface areas of plasmamodified WNS were very small (less than $1.2 \mathrm{~m}^{2} \mathrm{~g}^{-1}$ ). Importantly, as the UWM mass flow rate increased from 0.5 to 3 $\mathrm{g} \min ^{-1}$, the specific surface areas of the modified WNS decreased, whereas the $\mathrm{Cu}$ (II) removal efficiency increased. This indicated that physical adsorption was not a key factor in $\mathrm{Cu}$ (II) removal by modified WNS. The adsorption kinetics results of $\mathrm{Cu}(\mathrm{II})$ adsorption onto raw WNS and WNS-W3T15 are shown in Fig. 6 and Table 4. It can be seen that the Pseudo-second-order model satisfactorily fits the experimental data, with high correlation coefficients $\left(R^{2}\right.$ in the range of 0.9946 to 0.9985$)$ compared to the Pseudo-first-order model $\left(R^{2}\right.$ in the range of 0.9314 to 0.9669$)$ and the Weber-Morris model $\left(R^{2}\right.$ in the range of 0.8475 to 0.9029$)$. Furthermore, the calculated values of $q_{\mathrm{e}}$ according to the Pseudo-second-order model fitting were quite close to the experimental data. These results indicate that chemisorption dominates the $\mathrm{Cu}(\mathrm{II})$ adsorption process on raw WNS and UWM-plasma modified WNS. ${ }^{31}$

To investigate the components of modified WNS, element analyses were performed. As shown in Table 3, the O contents of modified WNS were higher than that of raw WNS, indicating that UWM-plasma modification added $\mathrm{O}$ atoms to the WNS surface. Moreover, the $\mathrm{O}$ content increased with increasing UWM mass flow rate in the plasma system. When increasing modification time, the O content of WNS-W3T15 increased to a maximum and then decreased from 15 to $30 \mathrm{~min}$. The $\mathrm{O}$ content of WNS-W3T15 was 50.01\% (wt\%); O was increased by about $5.5 \%$ compared to the raw WNS (44.33\%). During the UWM-plasma modification process, the $\mathrm{H}_{2} \mathrm{O}$ mist dissociated into reactive radicals of $\mathrm{O}$ and $\mathrm{OH}$, which are very powerful and nonselective oxidizing agents. ${ }^{21}$ The $\mathrm{H}_{2} \mathrm{O}$ dissociation in the plasma system can be given as follows: ${ }^{32,33} \mathrm{H}_{2} \mathrm{O}+\mathrm{e} \rightarrow \mathrm{H}+\mathrm{OH}+$ e and $\mathrm{OH}+\mathrm{e} \rightarrow \mathrm{O}+\mathrm{H}+\mathrm{e}$. When the plasma modification time was longer than 15 min, over-etching may have occurred. At this time, the $\mathrm{O}$ radicals on the WNS surface would be transformed to $\mathrm{O}_{2}$ according to the reaction: $\mathrm{O}+\mathrm{O}+\mathrm{e} \rightarrow \mathrm{O}_{2}+\mathrm{e} \cdot{ }^{32}$ Thus, the $\mathrm{O}$ content of WNS-W3T30 was lower than that of WNS-W3T15. In the UWM-plasma system, the presence of $\mathrm{O}$ and $\mathrm{OH}$ radicals can produce strong chemical oxidation effects and can generate O-containing functional groups on the WNS surface. It is known that O-containing functional groups (such as $-\mathrm{COOH}$ and $-\mathrm{OH}$ groups) are highly beneficial for the adsorption of $\mathrm{Cu}(\mathrm{II}){ }^{18} \mathrm{On}$ the other hand, the Cu content of freshly modified WNS (before $\mathrm{Cu}$ (II) adsorption) was $0 \%$, whereas $2.75 \% \mathrm{Cu}$ (wt base) was observed for the used WNS-W3T15 (after Cu(II) adsorption). This confirms that $\mathrm{Cu}(\mathrm{II})$ was adsorbed on the modified WNS surface.

Samples were analyzed by XPS to determine the chemical states present in UWM-plasma modified WNS. Fig. 7 shows the XPS survey spectra and $\mathrm{C}_{1 \mathrm{~s}}$ core level spectra for raw and plasma-modified WNS. As shown in Fig. 7a, carbon and oxygen are the main elements in raw WNS and UWM-plasma WNS; these peaks appear at $285 \mathrm{eV}\left(\mathrm{C}_{1 \mathrm{~s}}\right)$ and $531 \mathrm{eV}\left(\mathrm{O}_{1 \mathrm{~s}}\right)$, respectively. It is clear that the oxygen content significantly increased after UWM-plasma modification compared to the raw WNS. This result is consistent with the element analysis (as shown in Table 3 ), which confirms that the UWM-plasma modification process

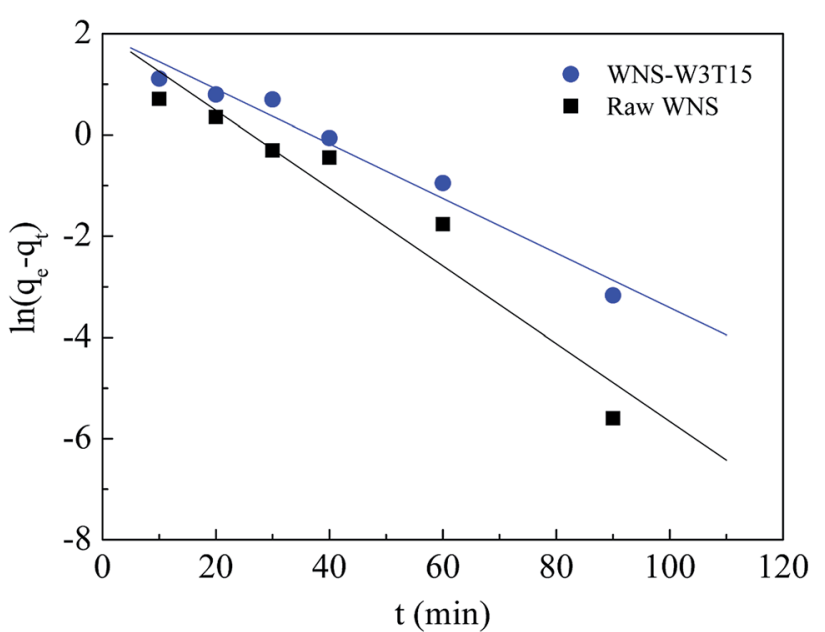

(a)

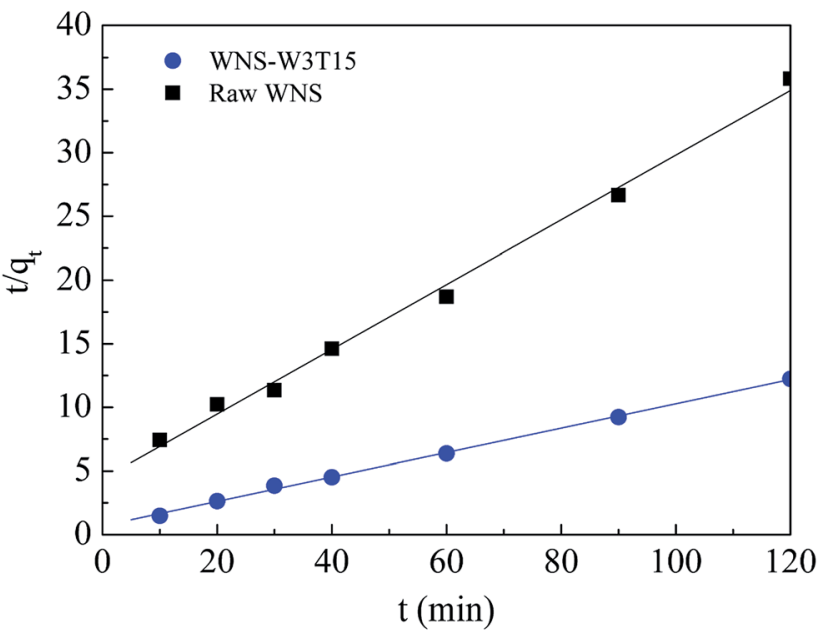

(b)

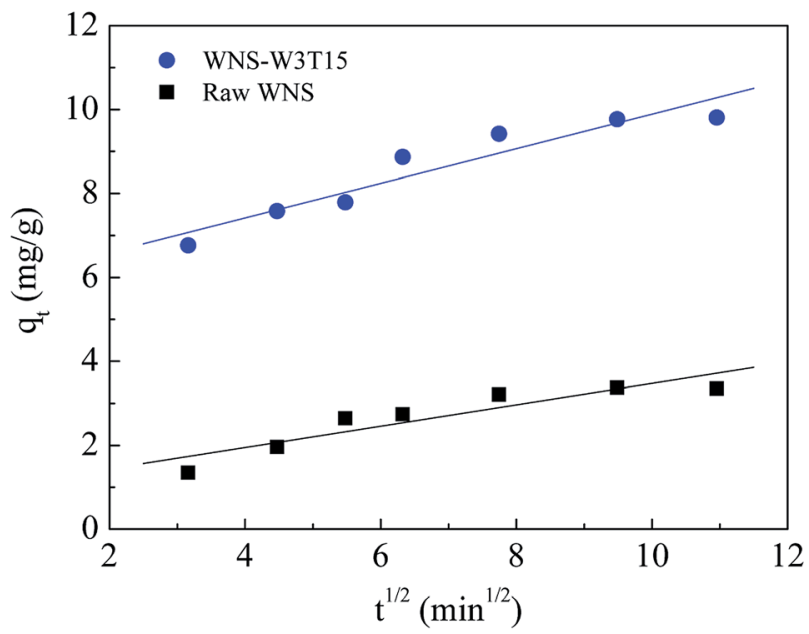

(c)

Fig. 6 Kinetics models for adsorption of CU(II) on raw WNS and WNSW3T15: (a) Pseudo-first-order model; (b) Pseudo-second-order model; (c) Weber-Morris model. 
Table 4 Kinetics parameters of the Pseudo-first order, Pseudo-second order and Weber-Morris models for Cu(I) adsorption on raw WNS and WNS-W3T15

\begin{tabular}{|c|c|c|c|c|c|c|c|c|c|c|}
\hline Sample & $\begin{array}{l}q_{\mathrm{e}} \exp \\
\left(\mathrm{mg} \mathrm{g}^{-1}\right)\end{array}$ & $\begin{array}{l}q_{\mathrm{e}} \mathrm{cal} \\
\left(\mathrm{mg} \mathrm{g}^{-1}\right)\end{array}$ & $\begin{array}{l}k_{1} \\
\left(\min ^{-1}\right)\end{array}$ & $R^{2}$ & $\begin{array}{l}q_{\mathrm{e}} \mathrm{cal} \\
\left(\mathrm{mg} \mathrm{g}^{-1}\right)\end{array}$ & $\begin{array}{l}k_{2} \\
\left(\mathrm{~g}\left(\mathrm{mg}^{-1} \min ^{-1}\right)\right)\end{array}$ & $R^{2}$ & $C$ & $\begin{array}{l}k_{\text {int }} \\
\left(\mathrm{mg}\left(\mathrm{g}^{-1} \min ^{1 / 2}\right)\right)\end{array}$ & $R^{2}$ \\
\hline Raw WNS & 3.35 & 7.56 & 0.077 & 0.9314 & 3.93 & 0.015 & 0.9946 & 0.9291 & 0.2545 & 0.8475 \\
\hline WNS-W3T15 & 9.81 & 7.31 & 0.054 & 0.9669 & 10.4 & 0.013 & 0.9985 & 5.7735 & 0.4112 & 0.9029 \\
\hline
\end{tabular}

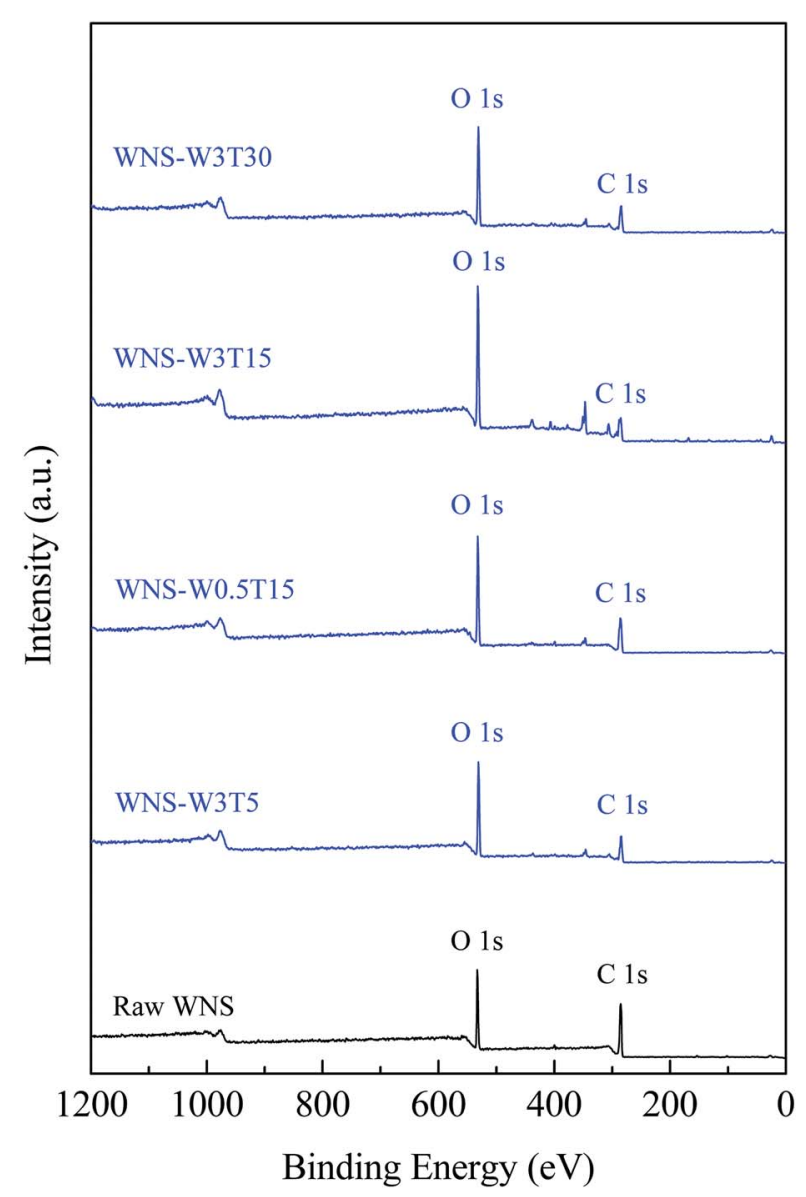

(a)

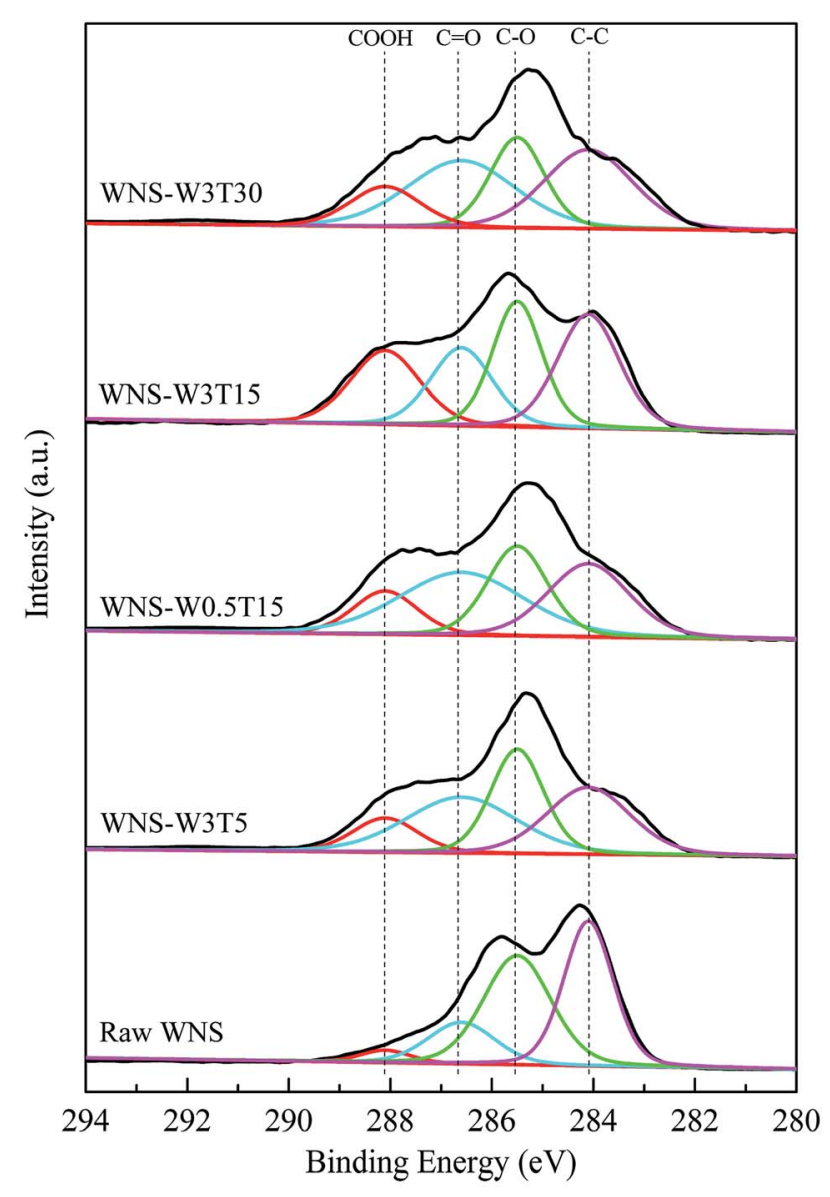

(b)

Fig. 7 XPS spectra of high-resolution scans for raw and UWM-plasma modified WNS: (a) total survey and (b) $C_{1 s}$ core level spectra.

loaded oxygen element on the WNS surface. As shown in Fig. 7b, the $\mathrm{C}_{1 \mathrm{~s}}$ spectrum can be fitted by four characteristic peaks for each sample. The peak at $284.1 \mathrm{eV}$ corresponds to $\mathrm{C}-\mathrm{C}$ groups, the peak located at $285.5 \mathrm{eV}$ is attributed to $\mathrm{C}-\mathrm{O}$ groups, and the binding energy peaks at $286.6 \mathrm{eV}$ and $288.1 \mathrm{eV}$ correspond to $\mathrm{C}=\mathrm{O}$ groups and $\mathrm{COOH}$ groups, respectively. The electron

Table 5 Functional groups of raw and UWM-plasma modified walnut shell from the XPS spectra of $C_{1 s}$

\begin{tabular}{|c|c|c|c|c|c|c|c|c|}
\hline \multirow{2}{*}{$\begin{array}{l}\text { Functional } \\
\text { group }\end{array}$} & \multirow{2}{*}{$\begin{array}{l}\text { Electron binding } \\
\text { energy }(\mathrm{eV})\end{array}$} & \multicolumn{7}{|c|}{ Relative intensity (\%) } \\
\hline & & WNS & WNS-W3T5 & WNS-W0.5T15 & WNS-W1.5T15 & WNS-W3T15 & Used WNS-W3T15 & WNS-W3T30 \\
\hline $\mathrm{C}-\mathrm{C}$ & 284.1 & 39.8 & 28.5 & 27.0 & 25.4 & 30.4 & 29.6 & 31.9 \\
\hline $\mathrm{C}-\mathrm{O}$ & 285.5 & 41.1 & 28.2 & 24.5 & 24.8 & 26.8 & 44.3 & 22.3 \\
\hline $\mathrm{C}=\mathrm{O}$ & 286.6 & 15.6 & 31.9 & 35.8 & 31.3 & 20.7 & 20.9 & 32.9 \\
\hline $\mathrm{COOH}$ & 288.1 & 3.5 & 11.4 & 12.7 & 18.5 & 22.1 & 5.2 & 12.9 \\
\hline
\end{tabular}


binding energies and relative intensities (calculated from the corresponding area of the small peak divided by the total area) of each peak are summarized in Table 5. It can be seen that the $\mathrm{COOH}$ group intensity of raw WNS was 3.5\%. After UWMplasma modification, the $\mathrm{COOH}$ group intensities of modified WNS were greatly increased. With increasing modification time from 5 to $15 \mathrm{~min}$, the $\mathrm{COOH}$ group intensity of modified WNS increased from $11.4 \%$ (WNS-W3T5) to $22.1 \%$ (WNS-W3T15). A further increase in modification time resulted in a decrease in $\mathrm{COOH}$ group content. It can be seen that the $\mathrm{COOH}$ group intensity of WNS-W3T30 was $12.9 \%$, which was less than that of WNS-W3T15. The COOH group content in WNS-W0.5T15 was $12.7 \%$, indicating that the increase of $\mathrm{H}_{2} \mathrm{O}$ content in the plasma system enhanced the production of $\mathrm{COOH}$ groups on the WNS surface. The changes in the $\mathrm{COOH}$ groups are consistent with the $\mathrm{O}$ element analysis data in Table 3 . This confirms that UWM-plasma generates $\mathrm{COOH}$ groups on the WNS surface. Based on the results of XPS analyses, the possible pathways for the formation and transformation of $\mathrm{COOH}$ groups during the UWM-plasma modification process can be described as follows:

$$
\begin{gathered}
\mathrm{H}_{2} \mathrm{O}+\mathrm{e} \rightarrow \mathrm{H}+\mathrm{OH}+\mathrm{e} \\
\mathrm{OH}+\mathrm{e} \rightarrow \mathrm{O}+\mathrm{H}+\mathrm{e} \\
\mathrm{C}+\mathrm{O} \rightarrow \mathrm{C}=\mathrm{O} \\
\mathrm{C}-\mathrm{H}+\mathrm{O} \rightarrow \mathrm{C}-\mathrm{OH} \\
\mathrm{C}=\mathrm{O}+\mathrm{OH} \rightarrow \mathrm{O}=\mathrm{C}-\mathrm{OH} \\
\mathrm{C}-\mathrm{OH}+\mathrm{O} \rightarrow \mathrm{O}=\mathrm{C}-\mathrm{OH}
\end{gathered}
$$

In the UWM-plasma system, high-energy active electrons collided with $\mathrm{H}_{2} \mathrm{O}$ molecules to form $\mathrm{O}$ and $\mathrm{OH}$ active radicals. The $\mathrm{C}$ and $\mathrm{C}-\mathrm{H}$ species on the WNS surface can react with $\mathrm{O}$ radicals by forming $\mathrm{C}=\mathrm{O}$ and $\mathrm{C}-\mathrm{OH}$ groups. Thereafter, the $\mathrm{C}=\mathrm{O}$ and $\mathrm{C}-\mathrm{OH}$ species react with $\mathrm{OH}$ and $\mathrm{O}$ radicals, respectively, and can be converted into $\mathrm{O}=\mathrm{C}-\mathrm{OH}$ groups. Consequently, the content of $\mathrm{COOH}$ groups on the WNS surface increased after UWM-plasma modification.

To explore the mechanism of $\mathrm{Cu}(\mathrm{II})$ adsorption on modified WNS, the XPS spectra of $\mathrm{Cu} 2 \mathrm{p}$ and $\mathrm{C}_{1 \mathrm{~s}}$ for fresh WNS-W3T15 and used WNS-W3T15 (after $\mathrm{Cu}(\mathrm{II})$ adsorption) were investigated, as shown in Fig. 8a and b, respectively. From Fig. 8a, two new peaks appeared at $932.9 \mathrm{eV}$ and $953.3 \mathrm{eV}$ after $\mathrm{Cu}$ (II) adsorption; these are representative of the +2 oxidation state for $\mathrm{Cu} 2 \mathrm{p}_{3 / 2}$ and $2 \mathrm{p}_{1 / 2},{ }^{34}$ respectively. This indicates that $\mathrm{Cu}(\mathrm{II})$ was successfully adsorbed on the modified WNS surface. As shown in Fig. 8b, after the $\mathrm{Cu}$ (II) adsorption process, the $\mathrm{COOH}$ group intensity in the used WNS-W3T15 decreased to $5.2 \%$. The C-O group intensity in the used WNS-W3T15 increased to $44.3 \%$. This implies that the $\mathrm{COOH}$ groups $(\mathrm{O}=\mathrm{C}-\mathrm{OH})$ changed into $\mathrm{C}-\mathrm{O}$ groups during the $\mathrm{Cu}(\mathrm{II})$ adsorption process. It is known that $\mathrm{COOH}$ groups are considered to be the decisive chemisorption sites in the $\mathrm{Cu}(\mathrm{II})$ adsorption process. ${ }^{\mathbf{1 4 , 1 8 , 3 5}}$ In this

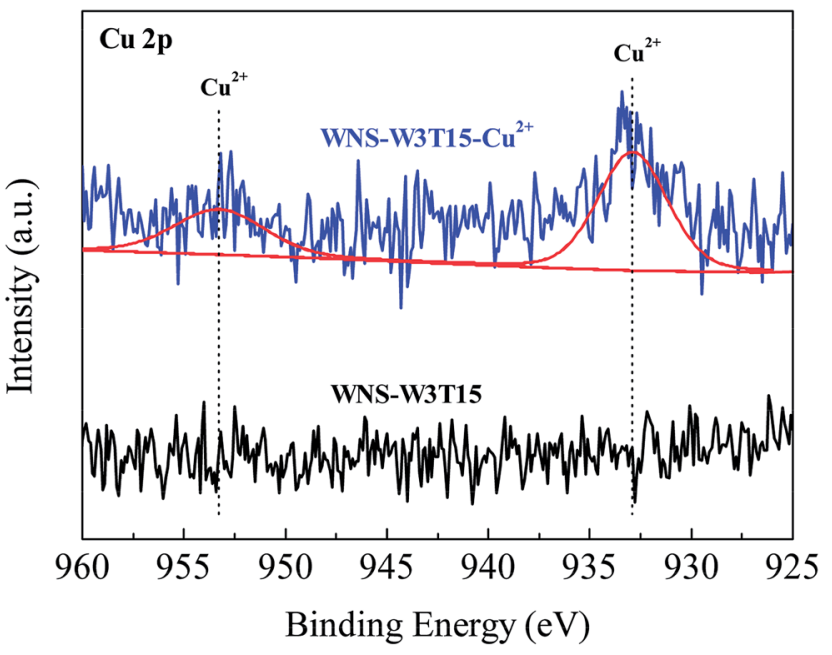

(a)

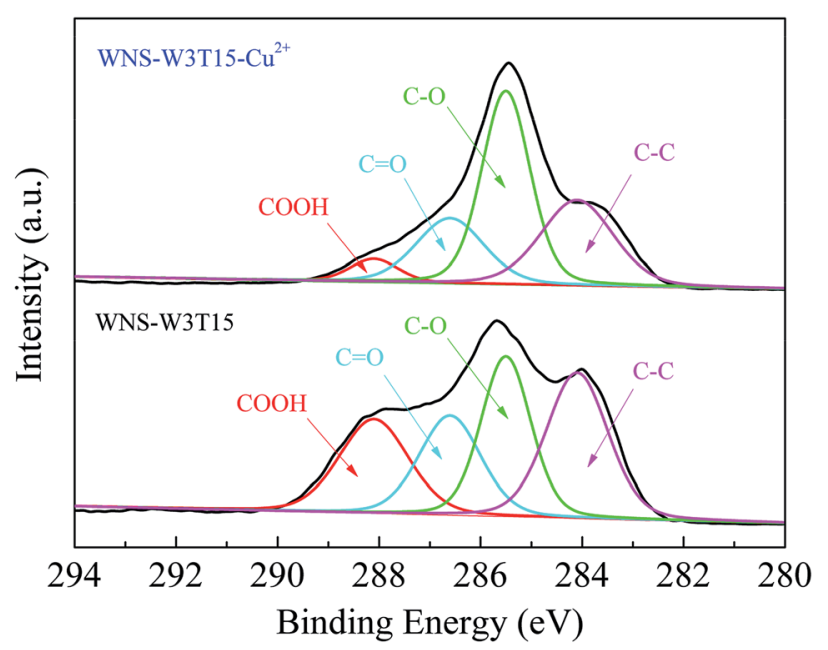

(b)

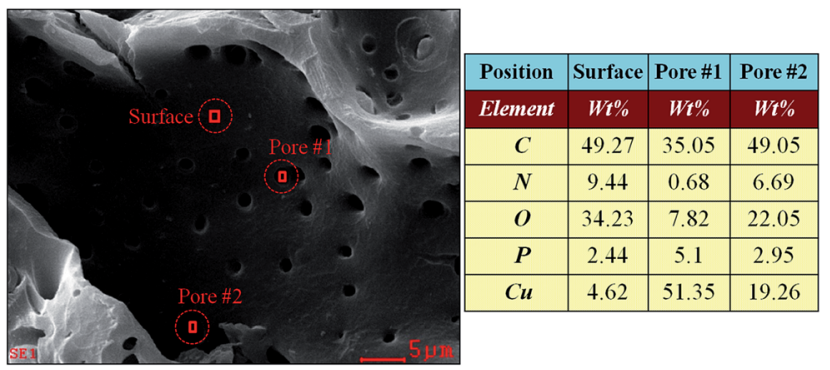

(c)

Fig. 8 (a) XPS spectra of Cu $2 p$ for WNS-W3T15 (before $\mathrm{Cu}^{2+}$ adsorption) and WNS-W3T15- $\mathrm{Cu}^{2+}$ (after $\mathrm{Cu}^{2+}$ adsorption); (b) XPS spectra of $C_{1 s}$ for WNS-W3T15 and WNS-W3T15-Cu ${ }^{2+}$; (c) SEM-EDX image of WNS-W3T15-Cu' ${ }^{2+}$.

study, UWM-plasma modification added new $\mathrm{COOH}$ active sites to the WNS surface and then enhanced $\mathrm{Cu}$ (II) adsorption by chemisorption, which occurred via ion exchange and/or complexation between positive charged $\mathrm{Cu}^{2+}$ and nonionized 
or ionized carboxylic groups $(\mathrm{COOH})$. The possible $\mathrm{Cu}$ (II) adsorption mechanism for UWM-plasma-modified WNS can be described by the following equations:

$$
\begin{gathered}
\mathrm{R}-\mathrm{O}=\mathrm{C}-\mathrm{OH}+\mathrm{Cu}^{2+} \rightarrow \mathrm{R}-\mathrm{O}=\mathrm{C}-\mathrm{OCu}^{+}+\mathrm{H}^{+} \\
\mathrm{R}-(\mathrm{O}=\mathrm{C}-\mathrm{OH})_{2}+\mathrm{Cu}^{2+} \rightarrow \mathrm{R}-(\mathrm{O}=\mathrm{C}-\mathrm{O})_{2} \mathrm{Cu}+2 \mathrm{H}^{+}
\end{gathered}
$$

To better understand the $\mathrm{Cu}(\mathrm{II})$ adsorption process on the modified WNS surface, SEM-EDX was used to analyze the distribution of adsorbed $\mathrm{Cu}$ (II) on the surface of used WNSW3T15. As shown in Fig. 8c, the adsorbed $\mathrm{Cu}(\mathrm{II})$ content on the external surface section was $4.62 \%$, whereas much more $\mathrm{Cu}$ (II) was observed to be adsorbed in the pore section $(51.35 \%$ $\mathrm{Cu}$ in pore \#1 and $19.26 \% \mathrm{Cu}$ in pore \#2). This implies that when $\mathrm{Cu}(\mathrm{II})$ diffused into the external surface of modified WNS, only a tiny fraction of $\mathrm{Cu}$ (II) was adsorbed. Most of the $\mathrm{Cu}$ (II) diffused into the pores which were caused by the plasma etching effect and was adsorbed at the activated sites of $\mathrm{COOH}$ groups which were produced via the UWM-plasma system.

\section{Conclusion}

A novel modification method was proposed to improve the content of $\mathrm{COOH}$ active sites on the surface of walnut shell using non-thermal plasma in ultrafine water mist for $\mathrm{Cu}$ (II) removal. The $\mathrm{Cu}$ (II) removal efficiency of raw walnut shell was $33.5 \%$; however, this efficiency increased to 98\% after UWMplasma modification. Specifically, the maximum $\mathrm{Cu}(\mathrm{II})$ adsorption capacity of UWM-plasma modified WNS $\left(39.4 \mathrm{mg} \mathrm{g}^{-1}\right)$ was 8 times that of the raw WNS $\left(5.02 \mathrm{mg} \mathrm{g}^{-1}\right)$ and is much higher than that of commercial activated carbon. Water mist was disassociated during plasma modification and $\mathrm{O}$ element was added to the WNS surface, which provided the requisite factor to generate activated sites of $\mathrm{COOH}$ groups. The relative intensity of the $\mathrm{COOH}$ groups was significantly enhanced by UWMplasma modification, which can accordingly improve the $\mathrm{Cu}(\mathrm{II})$ removal performance of WNS.

\section{Conflicts of interest}

There are no conflicts to declare.

\section{Acknowledgements}

The authors gratefully acknowledge financial support from the International Joint Research and Development Project of Tianjin Talent Introduction and Science \& Technology Cooperation Plan (14RCGFGX00850), National Key R\&D Program of China (2017YFD0400900), Scientific Research Foundation for Talents, Tianjin University of Science \& Technology (10286) and Innovation Fund for College student laboratory of Tianjin University of Science \& Technology (1701A301).

\section{References}

1 M. Li, Q. Liu, L. Guo, Y. Zhang, Z. Lou, Y. Wang and G. Qian, Bioresour. Technol., 2013, 141, 83.

2 A. Ostermann, Y. He, J. Siemens, G. Welp, A. Heuser, F. Wombacher, Q. Xue, X. Lin and W. Amelung, Environ. Sci. Technol., 2015, 49, 4609-4617.

3 B. Singha and S. K. Das, Colloids Surf., B, 2013, 107, 97-106.

4 J. Liu, F. Wang, W. Wu, J. Wan, J. Yang, S. Xiang and Y. Wu, Bioresour. Technol., 2018, 248, 127-134.

5 D. Mohan, A. Sarswat, Y. S. Ok and C. U. Pittman Jr, Bioresour. Technol., 2014, 160, 191-202.

6 X. Gao, L. Wu, Z. Li, Q. Xu, W. Tian and R. Wang, J. Mater. Cycles Waste Manage., 2017, 1-12.

7 Z. Li, X. Gao, L. Wu, K. Wang and N. Kobayashi, J. Porous Mater., 2017, 24, 193-202.

8 U. Farooq, J. A. Kozinski, M. A. Khan and M. Athar, Bioresour. Technol., 2010, 101, 5043-5053.

9 F. R. Oliveira, A. K. Patel, D. P. Jaisi, S. Adhikari, H. Lu and S. K. Khanal, Bioresour. Technol., 2017, 246, 110-122.

10 Y. Zhou, X. Liu, Y. Xiang, P. Wang, J. Zhang, F. Zhang, J. Wei, L. Luo, M. Lei and L. Tang, Bioresour. Technol., 2017, 245, 266-273.

11 X. Gao, L. Wu, Q. Xu, W. Tian, Z. Li and N. Kobayashi, Environ. Sci. Pollut. Res. Int., 2018, 1-9.

12 J. H. Zhang, H. Fu, X. S. Lv, J. Tang and X. H. Xu, Biomass Bioenergy, 2011, 35, 464-472.

13 M. Imamoglu and O. Tekir, Desalination, 2008, 228, 108-113. 14 N. C. Feng, X. Y. Guo and S. Liang, J. Hazard. Mater., 2009, 164, 1286-1292.

15 L. Wu, W. Wan, Z. Shang, X. Gao, N. Kobayashi, G. Luo and Z. Li, Sep. Purif. Technol., 2018, 197, 156-169.

16 B. Zhang, P. Xu, Y. Qiu, Q. Yu, J. Ma, H. Wu, G. Luo, M. Xu and H. Yao, Chem. Eng. J., 2015, 263, 1-8.

17 C. Chen, A. Ogino, X. Wang and M. Nagatsu, Diamond Relat. Mater., 2011, 20, 153-156.

18 S. Biniak, M. Pakula, G. S. Szymanski and A. Swiatkowski, Langmuir, 1999, 15, 6117-6122.

19 M. Vesali-Naseh, A. A. Khodadadi, Y. Mortazavi, A. A. Moosavi-Movahedi and K. Ostrikov, RSC Adv., 2016, 6, 31807-31815.

20 L. Pranevicius, S. Tuckute, K. Gedvilas and D. Milcius, Thin Solid Films, 2012, 524, 133-136.

21 Y. Du, G. Nayak, G. Oinuma, Z. Peng and P. J. Bruggeman, J. Phys. D: Appl. Phys., 2017, 50, 145-201.

22 F. N. Acar and Z. Eren, J. Hazard. Mater., 2006, 137, 909-914. 23 R. Baccar, J. Bouzid, M. Feki and A. Montiel, J. Hazard. Mater., 2009, 162, 1522.

24 L. Wu, Z. Shang, H. Wang, W. Wan, X. Gao, Z. Li and N. Kobayashi, J. Mater. Cycles Waste Manage., 2018, 1-13.

25 M. M. Rao, D. K. Ramana, K. Seshaiah, M. C. Wang and S. W. Chien, J. Hazard. Mater., 2009, 166, 1006-1013.

26 M. Kobya, E. Demirbas, E. Senturk and M. Ince, Bioresour. Technol., 2005, 96, 1518-1521.

27 J. P. Chen and S. Wu, J. Colloid Interface Sci., 2004, 280, 334342. 
28 A. M. Puziy, O. I. Poddubnaya, R. P. Socha, J. Gurgul and M. Wisniewski, Carbon, 2008, 46, 2113-2123.

29 C.-M. Chan, T.-M. Ko and H. Hiraoka, Surf. Sci. Rep., 1996, 24, 1-54.

30 S. Tang, N. Lu, J. K. Wang, S. K. Ryu and H. S. Choi, J. Phys. Chem. C, 2007, 111, 1820-1829.

31 K. S. Tong, M. J. Kassim and A. Azraa, Chem. Eng. J., 2011, 170, 145-153.
32 N. Médard, A. Jeanclaude Soutif and F. Poncinepaillard, Langmuir, 2002, 18, 2246-2253.

33 Q. Niu, J. Luo, Y. Xia, S. Sun and Q. Chen, Fuel Process. Technol., 2017, 156, 310-316.

34 M. V. Lombardo, M. Videla, A. Calvo, F. G. Requejo and G. J. A. A. Soler-Illia, J. Hazard. Mater., 2012, 223, 53-62.

35 L. Monser and N. Adhoum, Sep. Purif. Technol., 2002, 26, 137-146. 